\title{
Provisional Kuwaiti Children Hematology Reference Range
}

\begin{abstract}
Keywords: Pediatric; Ethnicity; Standardized; Interval; Kuwait Abstract

Introduction: Hematology reference ranges (HRR) in the third world countries usually based on results of measurements in advanced countries. Our HRR based on UK HRR since more than 5 decades. However, these parameters are affected by several factors including age, ethnicity, gender and environment. The goal of this study is to establish a provisional HRR for Kuwaiti children (CPK-HRR) and compare it with UK children hematology reference range (CUK-HRR).
\end{abstract}

Method: The blood results of 1200 normal child were collected from electronic data of 95,501 children and adults Kuwaiti. The children divided into 8 groups according to age and gender. The range of the $\mathrm{RBC}, \mathrm{Hb}, \mathrm{HCt}, \mathrm{MCV}, \mathrm{MCH}, \mathrm{MCHC}, \mathrm{RDW}, \mathrm{WBC}$ count, ANC, lymphocyte, monocyte, eosinophil, and basophil counts, PLT count, PMV, were evaluated to generate CPK-HRR.

Result: The Kuwaiti children HRR in their early life were insignificantly different from UK children HRR but from the age of 13 years old UP to the entire adult life, the differences between the two populations became clearly significant.

Conclusion: Kuwaiti pediatric population is different from UK pediatric population in the complete blood count parameters. This study supports the results of our previous adult provisional HRR. Generating regional children HRR is essential for proper diagnosis, treatment, and research work.

\section{Introduction}

Hematological and biochemical parameters are used to aid physicians to interpret results of clinical measurements. They may also be used in clinical trials as a guide to set inclusion and exclusion criteria as well as the basis of safety monitoring for trial participants. Reference values for third world countries usually based on results of measurements in advanced countries, which usually taken from package inserts with the accompanies reagent kits. However, these parameters even in the healthy state are affected by several factors including age, ethnicity, gender and environment including altitude $[1,2]$. These different periods of life require special hematological considerations for several reasons; first that the chemical makeup of the circulating red blood cells in children represented by their enzyme activities, and fetal hemoglobin content in the first days and months is not identical with that in later age. Second, the hematopoietic system of the infant and the child, like all other systems at these age periods, undergoes development modification, growth, peculiarly adapted to meet the requirements of these phases of age. This may affect the hematological parameters and result in different reference ranges for different age and gender groups [3]. Some hematological parameters show extensive physiological variation in the different period of life. At birth total red blood cell (RBC) count, hemoglobin $(\mathrm{Hb})$ level, hematocrit $(\mathrm{Hct})$ are shown to be higher than at any other period of life, which after few months of birth it becomes decrease [4]. Given that these laboratory parameters might be influenced by
Journal of

Hematology \& Thrombosis

\author{
Hassan Al-Jafar* \\ Department of Heamtology, Amiri Hospital, Kuwait City, Kuwait \\ *Address for Correspondence: \\ Hassan Al-Jafar, Consultant Hematologist, Department of Heamtology, \\ Amiri Hospital, Kuwait City, Kuwait, E-mail: cbc9@hotmail.com \\ Submission: 17 June, 2016 \\ Accepted: 04 July, 2016 \\ Published: 09 July, 2016 \\ Copyright: (c) 2016 Al-Jafar H. This is an open access article distributed \\ under the Creative Commons Attribution License, which permits \\ unrestricted use, distribution, and reproduction in any medium, provided \\ the original work is properly cited.
}

Reviewed \& Approved by: Dr. Raul H. Morales-Borges, American Red Cross in San Juan, Practices, Ashford Institute of Hematology \& Oncology, USA

differences in genetic, dietary and social other factors using reference values derived from another population might lead to wrong interpretations [5]. In the last decade, a small number of studies have been conducted in Africa demonstrating differences in normal values compared to those established in industrialized nations [6]. Recently Clinical and Laboratory Standards Institute's guidelines for establishing reference ranges note that "health is a relative condition lacking universal definitions" [7]. Few studies have been undertaken differences in normal values from industrialized populations, especially for hematologic indices. These differences suggest the need for the development of locally derived reference values for these parameters to improve clinical care. In establishing reference values, it is essential that the population be well defined and properly selected to be representative of that population [8]. The literature is very deficient on this subject. Although the studies conducted in different populations, have reported significant differences in different ethnic groups [9].

\section{Methods}

CBC analyses were performed using a Coulter LH-750/755 analyzer for Kuwaiti children and adults who visited Amiri hospital for various reasons. Amiri hospital provides services to the people in the great capital region of Kuwait. It serves about 500,000 people. The blood results were collected from children Kuwaiti individuals selected from the electronic data from October 2012-March 2013, after ensuring from the computer system registry that the selected individuals did not follow-up for any chronic disorders over up to up to April 2016. The numbers of the subject in our study were 95,501 approximately one third of them are in the pediatric age. According to the children age, 4 groups were created. Group 1, children age 1-2 years old, 150 female and 150 male, group 2, children age 3-6 years old, 150 female and 150 male, group 3, children age 7-12 years 150 female and 150 male, group 4 children age 13-17 years old, 150 female and 150 male. The sample represent Kuwaiti children fulfilling the criteria of normal individuals. The range of the RBC, Hb, Hct, MCV, $\mathrm{MCH}, \mathrm{MCHC}, \mathrm{RDW}, \mathrm{WBC}$ count, ANC, lymphocyte, monocyte, 
eosinophil, and basophil counts, PLT count, PMV, were evaluated to generate CPK-HRR.

\section{Data source}

The 1200 children were carefully collected from the electronic data system, age range, 1-17 years. The inclusion criteria were normal Kuwaiti children, males and females with normal blood sugar lipid, liver, and renal profiles. The entire study sample had no follow-up in any medical or out patient surgical departments up to April 2016 to confirm that no anemia due to chronic disorders. We excluded the patients with low serum ferritin level or abnormal high performance liquid chromatography (HPLC), blood sugar, renal function test, liver function test, and lipid profile to avoid inclusion of patients with anemia due to chronic disorders or hemoglobinopathies disorders.

\section{Results}

The obtained CPK-HRR and the CUK-HRR were as follow respectively:

For age 1-2 year old, RBC female 4.0-4.9 and (4.0-5.2), male 4.1-5.1 and (4.0-5.2). Hb female 105-126 and (111-141), male 105126 and (111-141). MCV female 72-84 and (68-84), male 70-81 and (68-84). MCH female 24-28 and (25-29), male 23-28 and (25-29). WBC female 6.7-16 and (6.0-16), male 6.5-16 and (6.0-16). PLTCNT female 227-438 and (200-550), male 211-431 and (200-550) Tables 1 and 2 . The results which could make differences in the diagnosis are illustrated in Figure 1.

For age 3-6 year old, RBC female 4.2-4.9 and (4.0-5.2), male 4.25.0 and (4.0-5.2). Hb female 112-127 and (110-140), male 110-127 and (110-140). MCV female 74-84 and (75-87), male 73-84 (75-87). MCH female 24-29 and (24-30), male 24-28 and (24-30). WBC female 6.2-15 and (5.0-15), male 5.9-15 and (5.0-15). PLTCNT female 219399 and (200-490), male 222-417 and (200-490) Tables 1 and 2. The results which could make differences in the diagnosis are illustrated in Figure 2.

For age 7-12 year old, RBC female 4.3-5.1 and (4.0-5.2), male 4.4-5.2 and (4.0-5.2). Hb female 117-137 and (115-155), male 118137 and (115-155). MCV female 76-86 and (77-95), male 74-86 and (77-95). MCH female 25-29 and (25-33), male 25-29 and (25-33). WBC female 5.8-13 and (5.0-13), male 5.6-13 and (5.0-13). PLTCNT female 226-368 and (170-450), male 244-386 and (170-450) Tables 1 and 2 . The results which could make differences in the diagnosis are illustrated in Figure 3.

For age 13-17 year old, RBC female 4.3-5.1 and (3.8-4.8), male 4.7-5.7 and (4.5-5.5). Hb female 119-140 and (120-150), male 131159 and (130-170). MCV female 77-90 and (83-101), male 77-90 and

Table 1: The points old differences between normal Kuwaiti and United Kingdom hematology reference ranges the in females which could change the diagnosis and the treatment.

\begin{tabular}{|c|c|c|c|c|c|c|c|c|c|c|c|c|c|}
\hline \multicolumn{2}{|c|}{ Female Group } & \multicolumn{3}{|c|}{ Age 1-2 years old } & \multicolumn{3}{|c|}{ Age 3-6 years old } & \multicolumn{3}{|c|}{ Age 7-12 years old } & \multicolumn{3}{|c|}{ Age 13-17 years old } \\
\hline Parameters & & median(mean $\pm S D)$ & CPK-HRR & $\begin{array}{l}\text { CUK- } \\
\text { HRR }\end{array}$ & $\operatorname{median}(m e a n \pm S D)$ & $\begin{array}{l}\text { CPK- } \\
\text { HRR }\end{array}$ & $\begin{array}{l}\text { CUK- } \\
\text { HRR }\end{array}$ & median(mean $\pm S D)$ & $\begin{array}{l}\text { CPK- } \\
\text { HRR }\end{array}$ & $\begin{array}{l}\text { CUK- } \\
\text { HRR }\end{array}$ & $\operatorname{median}(\operatorname{mean} \pm S D)$ & $\begin{array}{l}\text { CPK- } \\
\text { HRR }\end{array}$ & $\begin{array}{l}\text { CUK- } \\
\text { HRR }\end{array}$ \\
\hline RBC & $10^{9} / \mathrm{L}$ & $4.44(4.44 \pm 0.42)$ & $4.0-4.9$ & $\begin{array}{c}4.0- \\
5.2\end{array}$ & $4.51(4.54 \pm 0.38)$ & $4.2-4.9$ & $\begin{array}{c}4.0- \\
5.2\end{array}$ & $4.69(4.70 \pm 0.40)$ & $4.3-5.1$ & $\begin{array}{c}4.0 \\
-5.2\end{array}$ & $4.66(4.68 \pm 0.43)$ & $4.3-5.1$ & $3.8-4.8$ \\
\hline $\mathrm{Hb}$ & $g / L$ & $115(115.5 \pm 10.4)$ & $105-126$ & $\begin{array}{l}111- \\
141\end{array}$ & $120(119.9 \pm 7.64)$ & $\begin{array}{c}112- \\
127\end{array}$ & $\begin{array}{l}110- \\
140\end{array}$ & $129(126.9 \pm 9.85)$ & $\begin{array}{c}117- \\
137\end{array}$ & $\begin{array}{c}115- \\
155\end{array}$ & $129(129.6 \pm 10.3)$ & $119-140$ & $\begin{array}{c}120- \\
150\end{array}$ \\
\hline $\mathrm{HCT}$ & L/L & $0.35(0.35 \pm 0.03)$ & $\begin{array}{c}0.32- \\
0.38\end{array}$ & $\begin{array}{c}0.30- \\
0.38\end{array}$ & $0.36(0.36 \pm 0.02)$ & $\begin{array}{c}0.33- \\
0.38\end{array}$ & $\begin{array}{c}0.34- \\
0.40\end{array}$ & $0.38(0.38 \pm 0.03)$ & $\begin{array}{l}0.35- \\
0.41\end{array}$ & $\begin{array}{l}0.35- \\
0.45\end{array}$ & $0.39(0.39 \pm 0.03)$ & $\begin{array}{c}0.36- \\
0.42\end{array}$ & $\begin{array}{l}0.36- \\
0.46\end{array}$ \\
\hline MCV & $f / L$ & $79.0(78.1 \pm 5.60)$ & $72-84$ & $68-84$ & $80.0(79.3 \pm 5.00)$ & $74-84$ & $75-87$ & $82.0(81.2 \pm 5.29)$ & $76-86$ & $77-95$ & $85.0(83.7 \pm 6.65)$ & $77-90$ & $83-101$ \\
\hline $\mathrm{MCH}$ & pg. & $26.0(26.1 \pm 2.24)$ & $24-28$ & $25-29$ & $27.0(26.5 \pm 2.02)$ & $24-29$ & $24-30$ & $27.0(27.1 \pm 2.21)$ & $25-29$ & $25-33$ & $28.0(27.8 \pm 2.62$ & $25-30$ & $27-32$ \\
\hline $\mathrm{MCHC}$ & $\mathrm{g} / \mathrm{L}$ & $334(334.4 \pm 11.1)$ & $323-346$ & $\begin{array}{c}320- \\
360\end{array}$ & $333(334.1 \pm 10.8)$ & $\begin{array}{c}323- \\
345\end{array}$ & $\begin{array}{c}310- \\
370\end{array}$ & $335(331.6 \pm 26.8)$ & $\begin{array}{c}305- \\
358\end{array}$ & $\begin{array}{c}310- \\
370\end{array}$ & $332(332.0 \pm 8.13)$ & $324-340$ & $\begin{array}{l}315- \\
345\end{array}$ \\
\hline RDW & $\%$ & $13.8(14.2 \pm 1.69)$ & $12.5-16$ & & $13.6(13.8 \pm 1.18)$ & $\begin{array}{l}12.6- \\
15\end{array}$ & & $13.3(13.5 \pm 1.10)$ & $\begin{array}{c}12.4- \\
15\end{array}$ & & $13.5(13.9 \pm 2.01)$ & $11.9-16$ & $\begin{array}{c}11.6- \\
14\end{array}$ \\
\hline WBC & $10^{9} / \mathrm{L}$ & $10.6(11.1 \pm 4.35)$ & $6.7-16$ & $\begin{array}{c}6.0- \\
16\end{array}$ & $9.60(10.5 \pm 4.31)$ & $6.2-15$ & $\begin{array}{c}5.0- \\
15\end{array}$ & $8.65(9.52 \pm 3.75)$ & $5.8-13$ & $5.0-13$ & $8.50(8.93 \pm 3.00)$ & $5.9-12$ & $4.0-10$ \\
\hline NEUT \% & $\%$ & $45.6(46.9 \pm 19.1)$ & $28-66$ & & $52.8(54.5 \pm 17.9)$ & $37-72$ & & $55.9(58.9 \pm 16.1)$ & $43-75$ & & $62.0(63.0 \pm 13.5)$ & $50-77$ & $40-80$ \\
\hline LYMP \% & $\%$ & $41.6(41.6 \pm 18.1)$ & $23-60$ & & $35.6(34.7 \pm 16.5)$ & $18-51$ & & $33.0(30.6 \pm 13.7)$ & $17-44$ & & $27.1(27.5 \pm 11.7)$ & $16-39$ & $20-40$ \\
\hline MONO \% & $\%$ & $9.30(10.1 \pm 4.64)$ & $5.4-15$ & & $8.50(8.84 \pm 3.12)$ & $5.7-12$ & & $7.35(8.14 \pm 3.51)$ & $4.6-12$ & & $7.35(7.43 \pm 2.02)$ & $5.4-9$ & $2.0-10$ \\
\hline ESO \% & $\%$ & $0.40(1.12 \pm 1.65)$ & $<0.01-3$ & & $0.90(1.46 \pm 1.74)$ & $\begin{array}{c}<0.01 \\
-3\end{array}$ & & $1.15(1.97 \pm 2.38)$ & $\begin{array}{c}<0.01 \\
-4\end{array}$ & & $1.20(1.69 \pm 1.69)$ & $<0.01-3$ & $1.0-6$ \\
\hline BAS \% & $\%$ & $0.30(0.35 \pm 0.30)$ & $0.1-1$ & & $0.30(0.40 \pm 0.29)$ & $0.1-1$ & & $0.40(0.39 \pm 0.27)$ & $0.1-1$ & & $0.40(0.41 \pm 0.24)$ & $0.2-1$ & $<1.0-2$ \\
\hline NEUT A & $10^{9} / \mathrm{L}$ & $4.70(5.52 \pm 3.78)$ & $1.7-9$ & $1.0-7$ & $4.90(6.14 \pm 4.32)$ & $1.8-10$ & $1.5-8$ & $4.70(5.93 \pm 3.59)$ & $2.3-10$ & $2.0-8$ & $5.15(5.81 \pm 2.93)$ & $2.9-9$ & $2.0-7$ \\
\hline LYMP A & $10^{9} / \mathrm{L}$ & $4.10(4.63 \pm 4.29)$ & $0.3-9$ & $\begin{array}{c}3.5- \\
11\end{array}$ & $3.10(3.29 \pm 1.62)$ & $1.7-5$ & $6.0-9$ & $2.60(2.67 \pm 1.28)$ & $1.4-4$ & $1.0-5$ & $2.30(2.30 \pm 0.97)$ & $1.3-3$ & $1.0-3$ \\
\hline MONO A & $10^{9} / \mathrm{L}$ & $0.90(1.05 \pm 0.54)$ & $0.5-2$ & $0.2-1$ & $0.80(0.89 \pm 0.41)$ & $0.5-1$ & $0.2-1$ & $0.70(0.71 \pm 0.29)$ & $0.4-1$ & $0.2-1$ & $0.60(0.64 \pm 0.23)$ & $0.4-1$ & $0.2-1$ \\
\hline EOS A & $10^{\circ} / \mathrm{L}$ & $0.07(0.15 \pm 0.26)$ & $\begin{array}{c}<0.01- \\
0.4\end{array}$ & $0.1-1$ & $0.10(0.16 \pm 0.15)$ & $\begin{array}{c}<0.01- \\
0.3\end{array}$ & $0.1-1$ & $0.12(0.18 \pm 0.20)$ & $\begin{array}{c}<0.01- \\
0.04\end{array}$ & $\begin{array}{c}0.1- \\
1.0\end{array}$ & $0.10(0.15 \pm 0.14)$ & $0.01-0.3$ & $\begin{array}{c}0.02- \\
0.1\end{array}$ \\
\hline BAS A & $10^{9} / \mathrm{L}$ & $0.03(0.04 \pm 0.04)$ & $\begin{array}{c}<0.01- \\
0.1\end{array}$ & & $0.04(0.04 \pm 0.02)$ & $\begin{array}{c}0.02- \\
0.1\end{array}$ & & $0.03(0.03 \pm 0.02)$ & $\begin{array}{c}0.01- \\
0.1\end{array}$ & & $0.03(0.04 \pm 0.02)$ & $0.02-0.1$ & $\begin{array}{c}0.02- \\
0.1\end{array}$ \\
\hline PLTCNT & $10^{9 / L}$ & $330.5(332.5 \pm 106)$ & $227-438$ & $\begin{array}{l}200- \\
550\end{array}$ & $308(309 \pm 89.9)$ & $\begin{array}{c}219- \\
399\end{array}$ & $\begin{array}{c}200- \\
490\end{array}$ & $290(297 \pm 71.0)$ & $\begin{array}{c}226- \\
368\end{array}$ & $\begin{array}{l}170- \\
450\end{array}$ & $272(281 \pm 63.5)$ & $218-345$ & $\begin{array}{c}150- \\
410\end{array}$ \\
\hline MPV & $10^{9} / \mathrm{L}$ & $7.60(7.67 \pm 1.10)$ & $6.6-9$ & & $7.40(7.51 \pm 0.89)$ & $6.6-8$ & & $7.90(7.99 \pm 0.81)$ & $7.2-9$ & & $8.30(8.46 \pm 0.94)$ & $7.5-9$ & $7.0-11$ \\
\hline
\end{tabular}


Citation: Al-Jafar H. Provisional Kuwaiti Children Hematology Reference Range. J Hematol Thromb 2016;2(2): 6.

\section{ISSN: $2380-6842$}

Table 2: The points of differences between normal Kuwaiti and United Kingdom hematology reference ranges in males which could change the diagnosis and the treatment.

\begin{tabular}{|c|c|c|c|c|c|c|c|c|c|c|c|c|c|}
\hline \multicolumn{2}{|c|}{ Male Group } & \multicolumn{3}{|c|}{ Age 1-2 years old } & \multicolumn{3}{|c|}{ Age 3-6 years old } & \multicolumn{3}{|c|}{ Age 7-12 years old } & \multicolumn{3}{|c|}{ Age 13-17 years old } \\
\hline Parameters & & $\operatorname{median}(\operatorname{mean} \pm S D)$ & $\begin{array}{l}\text { CPK- } \\
\text { HRR }\end{array}$ & $\begin{array}{l}\text { CUK- } \\
\text { HRR }\end{array}$ & $\operatorname{median}(\operatorname{mean} \pm \mathrm{SD})$ & $\begin{array}{l}\text { CPK- } \\
\text { HRR }\end{array}$ & $\begin{array}{l}\text { CUK- } \\
\text { HRR }\end{array}$ & median(mean $\pm S D)$ & CPK-HRR & $\begin{array}{l}\text { CUK- } \\
\text { HRR }\end{array}$ & median(mean $\pm S D$ ) & CPK-HRR & $\begin{array}{l}\text { CUK- } \\
\text { HRR }\end{array}$ \\
\hline RBC & $10 \% / \mathrm{L}$ & $4.59(4.58 \pm 0.51)$ & $4.1-5.1$ & $4.0-5.2$ & $4.61(4.59 \pm 0.40)$ & $4.2-5.0$ & $4.0-5.2$ & $4.77(4.78 \pm 0.42)$ & $4.4-5.2$ & $\begin{array}{c}4.0 \\
-5.2\end{array}$ & $5.21(5.18 \pm 0.48)$ & $4.7-5.7$ & $4.5-5.5$ \\
\hline $\mathrm{Hb}$ & g/L & $115(115.3 \pm 10.4)$ & $\begin{array}{c}105- \\
126\end{array}$ & $\begin{array}{c}111- \\
141\end{array}$ & $119(119.4 \pm 8.98)$ & $\begin{array}{c}110- \\
128\end{array}$ & $\begin{array}{c}110- \\
140\end{array}$ & $128(127.3 \pm 9.40)$ & $118-137$ & $\begin{array}{c}115- \\
155\end{array}$ & $146(145.0 \pm 14.4)$ & $131-159$ & $\begin{array}{c}130- \\
170\end{array}$ \\
\hline HCT & L/L & $0.35(0.35 \pm 0.03)$ & $\begin{array}{c}0.32- \\
0.38\end{array}$ & $\begin{array}{c}0.30- \\
0.38\end{array}$ & $0.36(0.36 \pm 0.03)$ & $\begin{array}{c}0.33- \\
0.38\end{array}$ & $\begin{array}{c}0.34- \\
0.40\end{array}$ & $0.38(0.38 \pm 0.03)$ & & $\begin{array}{c}0.35- \\
0.45\end{array}$ & $0.44(0.43 \pm 0.04)$ & $\begin{array}{c}0.39- \\
0.47\end{array}$ & $\begin{array}{l}0.40- \\
0.50\end{array}$ \\
\hline $\mathrm{MCH}$ & pg. & $26.0(25.3 \pm 2.32)$ & $23-28$ & $25-29$ & $26.0(26.1 \pm 2.15)$ & $24-28$ & $24-30$ & $27.0(26.7 \pm 2.24)$ & $25-29$ & $25-33$ & $28.0(28.1 \pm 2.59)$ & $26-31$ & $32-27$ \\
\hline $\mathrm{MCHC}$ & g/L & $334(333.6 \pm 13.0)$ & $\begin{array}{l}321- \\
347\end{array}$ & $\begin{array}{c}320- \\
360\end{array}$ & $333(333.3 \pm 9.52)$ & $\begin{array}{c}324- \\
343\end{array}$ & $\begin{array}{c}310- \\
370\end{array}$ & $335(334.6 \pm 7.97)$ & $327-343$ & $\begin{array}{c}310- \\
370\end{array}$ & $337(335.1 \pm 9.20)$ & $326-344$ & $\begin{array}{c}315- \\
345\end{array}$ \\
\hline RDW & $\%$ & $14.5(14.7 \pm 1.60)$ & $13.1-16$ & & $13.7(14.0 \pm 1.21)$ & $12.8-15$ & & $13.5(13.7 \pm 1.09)$ & $12.6-15$ & & $3.5(13.7 \pm 1.42)$ & $12.2-15$ & $11.6-14$ \\
\hline WBC & $10^{9} / \mathrm{L}$ & $10.4(11.1 \pm 4.59)$ & $6.5-16$ & $6.0-16$ & $9.70(10.4 \pm 4.44)$ & $5.9-15$ & $5.0-15$ & $8.50(9.37 \pm 3.82)$ & $5.6-13$ & $5.0-13$ & $8.30(8.62 \pm 3.08)$ & $5.5-12$ & $4.0-10$ \\
\hline NEUT \% & $\%$ & $41.9(43.0 \pm 19.2)$ & $24-62$ & & $54.0(54.6 \pm 17.7)$ & $37-72$ & & $58.7(58.0 \pm 17.6)$ & $40-76$ & & $61.0(61.2 \pm 15.2)$ & $46-76$ & $40-80$ \\
\hline LYMP \% & $\%$ & $42.1(44.7 \pm 18.2)$ & $26-63$ & & $33.3(33.8 \pm 16.3)$ & $18-50$ & & $30.1(30.7 \pm 15.4)$ & $15-46$ & & $26.9(27.6 \pm 12.9)$ & $15-41$ & $20-40$ \\
\hline ESO \% & $\%$ & $0.55(1.16 \pm 1.37)$ & $<0.01-3$ & & $1.10(1.98 \pm 2.47)$ & $\begin{array}{c}<0.001 \\
-4\end{array}$ & & $1.70(2.55 \pm 3.15)$ & $<0.01-6$ & & $1.95(2.45 \pm 2.20)$ & $0.3-5$ & $1.0-6$ \\
\hline BAS \% & $\%$ & $0.40(0.39 \pm 0.23)$ & $0.2-1$ & & $0.30(0.36 \pm 0.22)$ & $0.1-1$ & & $0.30(0.43 \pm 0.45)$ & $<0.01-1$ & & $0.40(0.43 \pm 0.33)$ & $0.1-1$ & $<1.0-2$ \\
\hline NEUT A & $10^{9} / \mathrm{L}$ & $3.95(5.02 \pm 3.58)$ & $1.4-9$ & $1.0-7$ & $4.70(6.08 \pm 4.25)$ & $1.8-10$ & $1.5-8$ & $4.80(5.81 \pm 3.87)$ & $2.0-10$ & $2.0-8$ & $5.20(5.60 \pm 3.09)$ & $2.5-9$ & $2.0-7$ \\
\hline LYMP A & $10^{9} / \mathrm{L}$ & $4.35(4.77 \pm 2.53)$ & $2.2-7$ & $3.5-11$ & $2.85(3.16 \pm 1.66)$ & $1.5-5$ & $6.0-9$ & $2.50(2.57 \pm 1.25)$ & $1.3-4$ & $1.0-5$ & $2.10(2.12 \pm 0.85)$ & $1.3-3$ & $1.0-3$ \\
\hline MONO A & $10^{9} / \mathrm{L}$ & $1.00(1.13 \pm 0.57)$ & $0.6-2$ & $0.2-1$ & $0.80(0.92 \pm 0.47)$ & $0.5-1$ & $0.2-1$ & $0.70(0.73 \pm 0.29)$ & $0.4-1$ & $0.2-1$ & $0.60(0.67 \pm 0.27)$ & $0.4-1$ & $0.2-1$ \\
\hline EOS A & $10^{9} / \mathrm{L}$ & $0.11(0.16 \pm 0.18)$ & $\begin{array}{c}<0.01- \\
0.3\end{array}$ & $0.1-1$ & $0.14(0.22 \pm 0.29)$ & $<0.01-1$ & $0.1-1$ & $0.15(0.24 \pm 0.29)$ & $<0.01-1$ & $0.1-1.0$ & $0.16(0.20 \pm 0.18)$ & $0.02-0.4$ & $\begin{array}{c}0.02- \\
0.5\end{array}$ \\
\hline BAS A & $10^{9} / \mathrm{L}$ & $0.04(0.04 \pm 0.03)$ & $\begin{array}{c}0.01- \\
0.1\end{array}$ & & $0.03(0.03 \pm 0.02)$ & $\begin{array}{r}0.02 \\
-\quad 0.1\end{array}$ & & $0.03(0.04 \pm 0.03)$ & $0.01-0.1$ & & $0.03(0.04 \pm 0.03)$ & $0.01-0.1$ & $\begin{array}{c}0.02- \\
0.1\end{array}$ \\
\hline PLTCNT & $10^{9} / \mathrm{L}$ & $303(321 \pm 110)$ & $\begin{array}{c}211- \\
431\end{array}$ & $\begin{array}{l}200- \\
550\end{array}$ & $304(320 \pm 97.8)$ & $\begin{array}{c}222- \\
417\end{array}$ & $\begin{array}{c}200 \\
-490 \\
\end{array}$ & $312(315 \pm 70.7)$ & $244-386$ & $\begin{array}{l}170- \\
450\end{array}$ & $256(259 \pm 58.5)$ & $201-318$ & $\begin{array}{c}150- \\
410\end{array}$ \\
\hline MPV & $10^{9} / \mathrm{L}$ & $7.50(7.59 \pm 0.86)$ & $6.7-8$ & & $7.50(7.52 \pm 0.86)$ & $6.7-8$ & & $7.90(7.99 \pm 0.98)$ & $7.0-9$ & & $8.30(8.38 \pm 0.90)$ & $7.5-9$ & $7.0-11$ \\
\hline
\end{tabular}
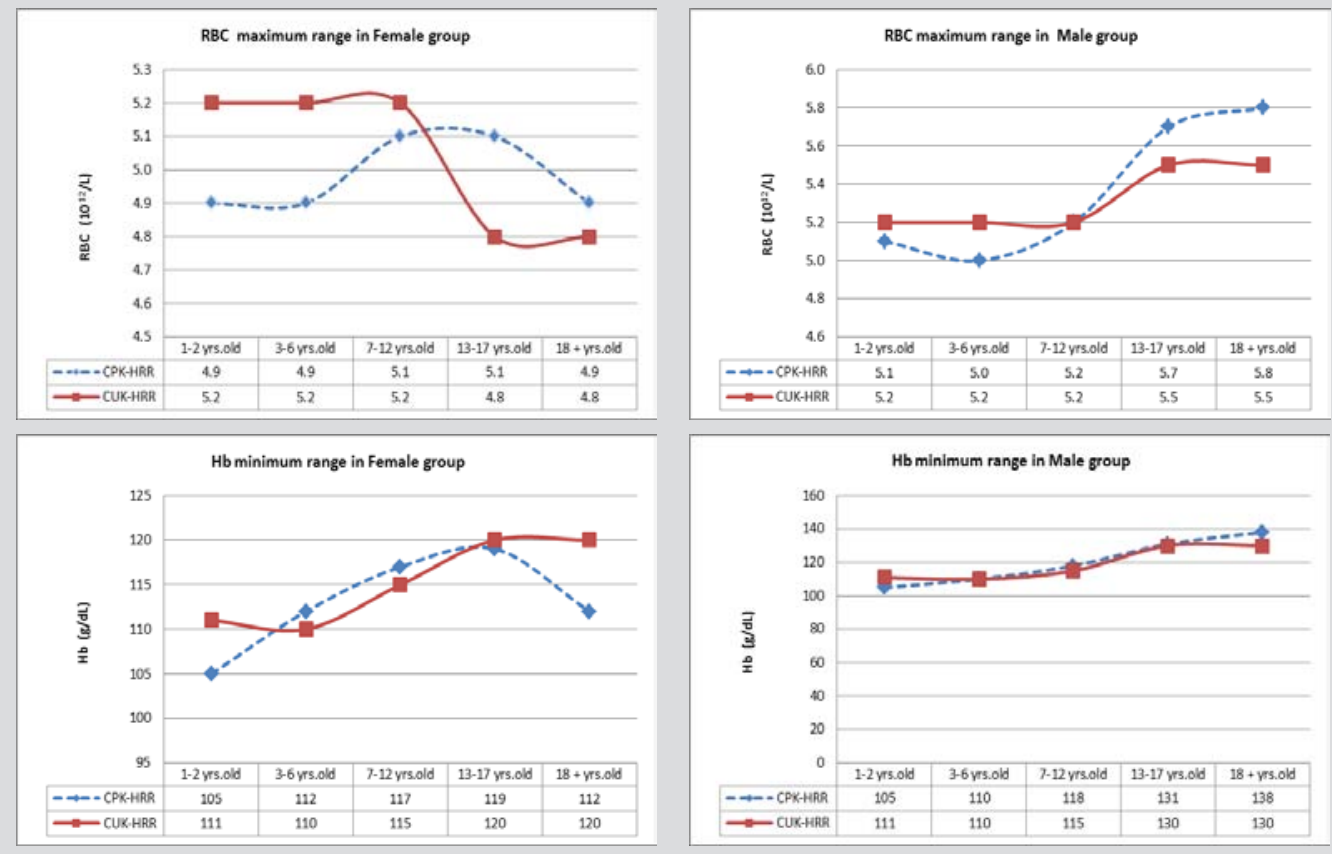

Figure 1: (A) The female RBC in the older age show in the maximum range more count in older age. (B) The male RBC in the older age show in the maximum range more count in older age. (C) The female HB in the older age show in the minimum range less level in older age. (D) The male HB in the older age show in the minimum range less level in older age. 


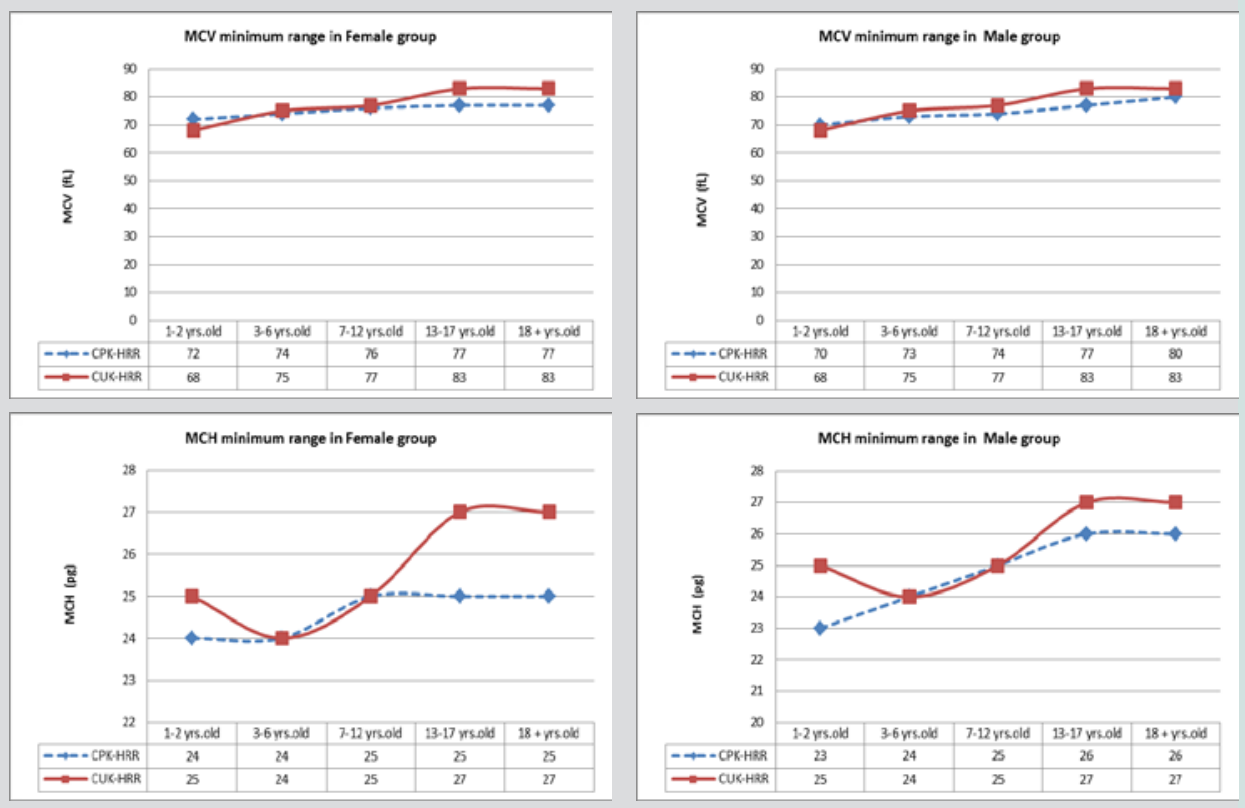

Figure 2: (A) The female $\mathrm{Hb}$ show in the minimum range less level in older age. (B) The female MCV show in the minimum range less level in older age. (C) The female $\mathrm{MCH}$ show in the minimum range less level in older age. (D) The male $\mathrm{MCH}$ in the older age show lower color in older age.

(83-101). MCH female 25-30 and (27-32), male 26-31 and (27-32). WBC female 5.9-12 and (4.0-10), male 5.5-12 and (4.0-10) PLTCNT female 218-345 and (150-410), male 201-318 and (150-410) Tables 1 and 2 . The results which could make differences in the diagnosis are illustrated in Figure 3.

\section{Discussion}

In Kuwait, there are no elaborate studies available locally which could help in formulating reference ranges for hematological indices. The goal of this research study is to establish children provisional Kuwaiti Hematological reference ranges (CPK-HRR), to help the clinicians in comparing the laboratory test results with locally generated reference ranges. Hematology reference ranges are a useful tool to diagnose accurately and hence manage the underlying diseases. Moreover, appropriate diagnosis and treatment can reduce the infant and children morbidity and mortality rates [10]. In several studies significant differences in hematology reference range have been found in children at various ages and adolescents in different populations, seasons, racial ethnic groups, and gender subgroups $[11,12]$.

RBC count in CPK-HRR below 13 year old did not show a significant change from CUK-HRR in both genders. However, from the age 13 and above the result of CPK-HRR in comparison to CUKHRR was significantly different in the age wise but again not from the gender point of veiw. The age group 13-17 results are the closest group to the adults; this group RCB count female range 4.3-5.1 and (3.8-4.8), the male 4.7-5.7 and (4.5-5.5) that result show higher RBC level range in Kuwaiti children. The $\mathrm{Hb}$ also became significant in this age group, female 119-140 and (120-150), while in male 131-159 and (130-170) that result show the lower Hb range in Kuwaiti children. The MCV in female 77-90 and (83-101), while in male 77-90 and (83-
101) that result show the lower MCV range in Kuwaiti children. The $\mathrm{MCH}$ in female 25-30 and (27-32), in male 26-31 and (27-32) that result show the lower $\mathrm{MCH}$ range in Kuwaiti children. The $\mathrm{RBC}, \mathrm{Hb}$, $\mathrm{MCV}$ and $\mathrm{MCH}$ range in values differences in the age group 13-17 are significant and supporting our previous study on Adult Provisional Kuwaiti Hematological Reference Range, which gave similar outcome to the 13-17 age group [2]. The $\mathrm{RBC}, \mathrm{Hb}, \mathrm{MCV}$ and $\mathrm{MCH}$ different range values between Kuwait and the UK are not significant in the age groups below 13 years it could be because the hematopoietic system is physiologically more active since new born with a lot of bizarre morphological pictures at that age which stabilize towards the normal morphology over a long time (Tables 1 and 2) (Figure 1) [3].

WBC: In comparison to other studies we did not find differences by gender in both total WBC and ANC count in CPKHRR and CUK-HRR in the age groups below 13 years, but from 13 years old and above towards adulthood, both total WBC count and ANC found to be significantly higher in Kuwaiti children population without being having any infectious or active diseases. In 13-17 years old total WBC count in female 5.9-12 and (4.0-10), the ANC 2.9-9 and (2-7 ). In male WBC 5.5-12 and (4.0-10), the ANC 2.5-9 and (2.0-7). Platelets counts observed in Kuwaiti children are always higher than in the UK children platelets reference range, and also there is no evidence of gender differences. The high level of platelets in Kuwaiti children is not related to infection or active disease. This finding is similar to our findings in the adult prevalence Kuwait hematology reference range (Tables 1 and 2) (Figure 1).

The development of regional specific reference values is essential for efficient patient diagnosis and management and proper conduct of regional clinical research. Ethnic origin, genetics, gender, altitude, and environmental factors, especially pathogens, may influence some 


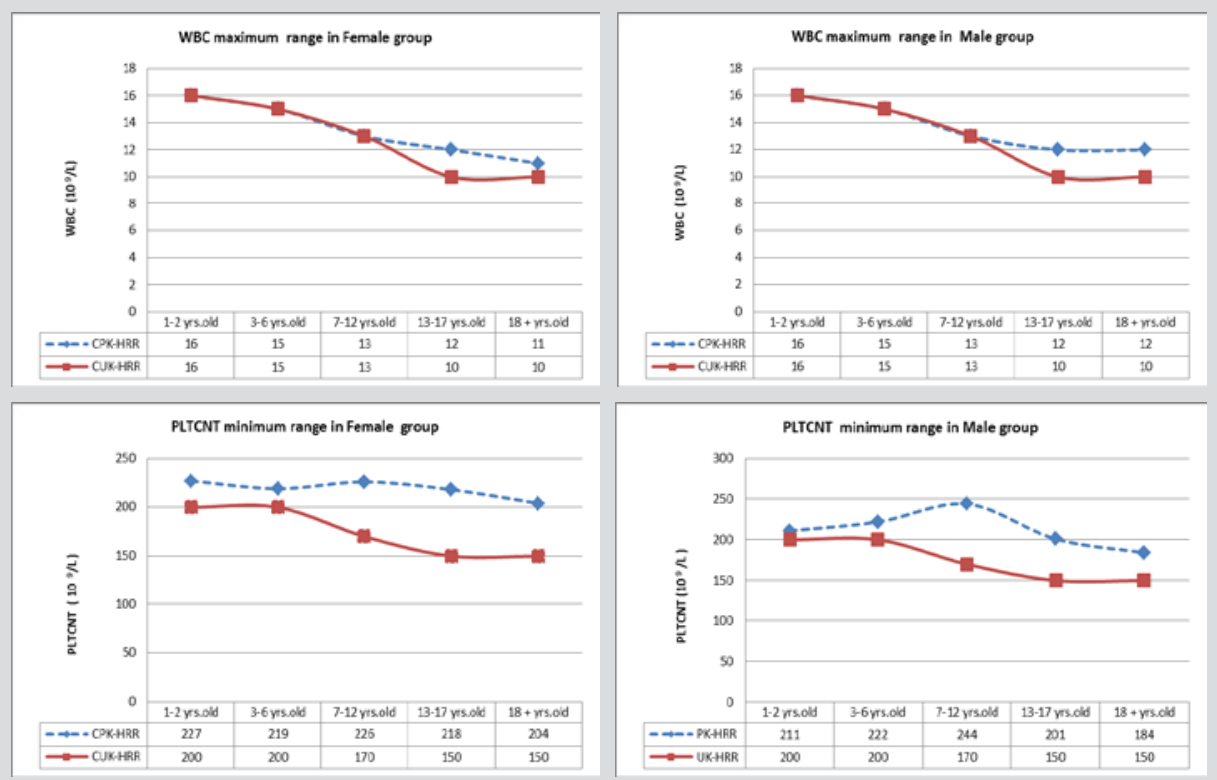

Figure 3: (A) The female WBC in the maximum range show higher count in older age. (B) The male WBC in the maximum range show higher count in older age. (C) The female Platelets in the minimum range show higher count in older age. (D) The male Platelets in the minimum range show higher count in older age.

values of hematologic indices, suggesting that the development of reference values may be beneficial for the improved quality of health care [13]. Genetic factors have been found to significantly contribute to all blood cell measures. In almost all studies, the ethnic and sex differences impact are significant [14]. This study has covered the whole pediatric age range from 1-17 years, separately in males and females, to determine the value of hematological parameters. The hematological reference ranges currently in use since more than 5 decades in state of Kuwait hematology laboratories are derived from the normal range of CUK-HRR. This research needs to be conducted on a higher scale in different provinces in Kuwait to confirm the significant finding of this study for more accurate result and to stabilized as a national Kuwait standard hematology reference range. The same study is essential in other developing countries to establish their reference ranges in hematology and biochemistry laboratories.

\section{Limitation}

The same limitation applies to the adult study. The children hematology reference ranges in this study were calculated from a large pediatric Kuwaiti population in the capital area; however, only 1,200 normal children were selected from the 95,501 Kuwaiti subjects who visited our institute over 6 months. Furthermore, we did not have the HPLC and serum ferritin values of all the selected subjects. In patients with normal serum ferritin and normal HPLC pattern still they could be alpha thalassemia trait, but it is impossible to perform DNA analysis for 1200 children because of the high cost and the nonavailability of this test in the routine laboratories.

The strengthening point in this study that in many wellinvestigated families with no family history of hemoglobinopathies, their $\mathrm{CBC}$ showed high $\mathrm{RBC}$, low $\mathrm{Hb}, \mathrm{MCV}$ and $\mathrm{MCH}$ according to UK-HRR but they are normal according to PK-HRR. However, because of the significant results, this study must be conducted in other regions of this country, and the samples should be collected from healthy volunteers and the molecular DNA analysis to be applied as much as possible for the molecular confirmation.

\section{Conclusion}

Generating regional children hematology reference range is essential for proper diagnosis, treatment, and research work. The Kuwaiti pediatric population is different from UK pediatric population in $\mathrm{RBC}, \mathrm{Hb}, \mathrm{MCV}, \mathrm{MCH}, \mathrm{WBC}, \mathrm{ANC}$ and platelets levels. In the early life there were slight differences between the two populations but from the age of 13 years old up to the entire adult life, the difference between the two populations are clearly significant. This study supports the results of our previous study of the Adult Hematology Reference Range comparison between the Kuwait and UK populations.

\section{Study Approval}

This study approved by the Joint Committee for the Protection of Human Subjects in Research, reference number: VDR/179, subject title: "Detecting the normal hematology values and the incidence of the different types of anemia in random samples obtained from Kuwaiti people referred to Al-Amiri Hospital in the great capital area".

\section{References}

1. Koram K, Addae M, Ocran J, Adu-Amankwah S, Rogers W, et al. (2007) Population based reference intervals for common blood haematological and biochemical parameters in the akuapem north district. Ghana Med J 41: 160166.

2. Al-Jafar HA (2016) Provisional study of Kuwait adult hematology reference range. J Hematol Thromb 2: 1-4.

3. Buseri FI, Siaminabo IJ, Jeremiah ZA (2010) Reference values of hematological indices of infants, children, and adolescents in Port Harcourt, 
Citation: Al-Jafar H. Provisional Kuwaiti Children Hematology Reference Range. J Hematol Thromb 2016;2(2): 6.

ISSN: $2380-6842$

Nigeria. Pathol Lab Med Int 2: 65-70.

4. Sahoo D, Gosai H, Harsoda JM, Palan BM (2015) A comparative hematological profile study among young individuals. Can J Basic Appl Sci 3: 178-181.

5. Odutola AA, Afolabi MO, Jafali J, Baldeh I, Owolabi OA, et al. (2014) Haematological and biochemical reference values of Gambian infants. Trop Med Int Health 19: 275-283.

6. Buchanan AM, Muro FJ, Gratz J, Crump JA, Musyoka AM, et al. (2010) Establishment of haematological and immunological reference values for healthy Tanzanian children in Kilimanjaro Region. Trop Med Int Health 15 1011-1021.

7. Manning L, Laman M, Townsend MA, Chubb SP, Siba PM, et al. (2011) Reference intervals for common laboratory tests in Melanesian children. Am J Trop Med Hyg 85: 50-54.

8. Horowitz GL (2008) Reference intervals: practical aspects. eJIFCC 19: 1-11.
9. Nubila T, Ukaejiofo EO, Nubila NI, Shu EN, Okwuosa CN, et al. (2014) Hematological profile of apparently healthy blood donors at a tertiary hospital in Enugu, south east Nigeria: A pilot study. Niger J Exp Clin Biosci 2: 33-36.

10. Keramati MR, Mohammadzadeh A, Farhat AS (2010) The determination of haematological reference values in neonates in Mashard. Horizon Med Sci 16: 64-71.

11. Bain BJ (1996) Ethnic and sex differences in the total and differential white cell count and platelet count. J Clin Pathol 49: 664-666.

12. Taylor MR, Holland CV, Spencer R, Jackson JF, O'Connor GI, et al. (1997) Haematological reference ranges for schoolchildren. Clin Lab Haematol 19: $1-15$.

13. Lugada ES, Mermin J, Kaharuza F, Ulvestad E, Were W, et al. (2004) Population-based hematologic and immunologic reference values for a healthy Ugandan population. Clin Diagn Lab Immunol 11: 29-34.

14. Nduka N, Aneke C, Maxwell-Owhochuku S (1988) Comparison of some haematological indices of Africans and Caucasians resident in the same Nigerian environment. Haematologica (Budap) 21: 57-63.

\section{Acknowledgements}

Great thankful for the haematology laboratory staff in Amiri Hospital for facilitating this work. 